\title{
NOTES ON THE NOMENCLATURE OF SCYMNUS OR SCYMNORHINUS, A GENUS OF SHARKS.
}

\author{
By Theodore Gill, LL. D.
}

The SHARK genus generally known under the name Scymnus can not retain that name. To show why it can not and what should be its substitute is the object of the present communication.

I.

The name scymnus was given to the genus of sharks by Cuvier in 1817; the same name had been given by Kugelmann in 1794 to a genus of coccinelloid beetles, and is still in use, the insect genus now comprising very numerous species. Therefore, the use of the appellation in ichthyology is precluded. Several names are available as substitutes.

II.

In 1810 Rafinesque gave the name Dalatias to a genus distinguished from his Squalus (Acanthias) by the alleged absence of spiracles. Our knowledge of the Mediterranean fauna and Rafinesque's descriptions otherwise enable us to identify the two species which he refers to Dalatias and to assume that the spiracles must have been present in both of them. The D. sparophagus was a Scymnus; the D. nocturnus a typical Squalus. Dabatias of Rafinesque was, therefore, a synonym of Squalus of Rafinesque, and the result of a blunder and failure of observation.

III.

In 1839 Swainson adopted the genus "Dalatias, Raf." but limited it to $D$. nocturnus, incorporating with the generic diagnosis, characters derived from the specific diagnosis given by Rafinesque (furnished with anterior spines, ete.) of D. nocturnus.

IV.

In 1816 Bonaparte first substituted for the name Scymnus the new term Scymnorhinus, doubtless for the reason that he had ascertained that the coleopterous genus had received the former name before the selachian. 
V.

In 1850 Gray revived the name Dalatias for the Scymni, on the ground of priority for the former and not because Scymnus was preoccupied.

VI.

I conclude that Dalatias was to all intents and purposes a pure synonym of Squalus, and the addition of a species of another genus was surely insufficient to affect its character. Scymnus would therefore have been available as the first independent name of the shark genus, so called, had it not been already used. Under the circumstances, however, Dalatias might have been revived with the modified sense attributed to it by Gray, if its revival had not been precluded by other considerations. But the previous limitation of Dalatias by Swainson and substitution of a new name by Bonaparte barred such revival. The name given by Bonaparte must therefore be used for the Scymni of Cuvier. .

VII.

The following synonymy will give other data respecting the names referred to:

\section{Genus SCYMNORHINUS.}

<Les Leiches (Scymnus), Cuvier, Règne Animal, II, p. 130, 1817; 2d ed., II, p. 392.1829 (not of Kugelmann, 1794).

<Scymnorhinus, Bonaparte, Cat. Met. Pesci Europei, p. 16, 1846.

<Dalatias, Gray, List Fishes Brit. Mus., I, p. 75, 1851.

We may congratulate ourselves that such a barbarous compound as Dalatias (of unknown formation) need not be used. Scymnorhinus has the merit of being of classical origin and correct formation, although meaningless ${ }^{1}$ as a denominator of generic characteristics.

\section{VIII.}

The change of the generic name entails a corresponding change in the name of the family of which the genus is the type. The nomenclature of that family is summarized in the following synonymy:

\section{Family SOMNIOSID E.}

<Abtheilung der Haifische, Müller and Henle, Archiv Naturgesch., 3. Jahrg., I, p. 399, 1837.

< Fourth division of Sharks, Müller and Henle, Mag. Nat. Hist., n. s., II, p. $88,1838$.

<Seymni, Müller and Henle, Syst. Beschreib. Plagiostomen, p. 91, 1841.

<Scymnida, Adams, Man. Nat. Hist., p. 89, 1854.

<Scymnida, Richardson, Encyel. Brit., 8th ed., XII, p. 325, 1856.

<Scymnoidei, Bleeker, Enum. Sp. Piscium Archipel. Indico, p. xii, 1859.

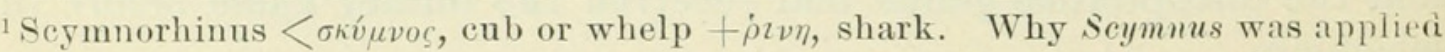
to beetles is not evident; it may have been given in allusion to their small size. 
< Scymnoida, Gill, Aun. N. Y. Lyceum Nat. Hist., VII, p. 405, 1862. <Scymni, A. Duméril, Hist. Nat. Poiss., I, pp. 310, 450, 1865.

<Spinacida, Günther, Cat. Fish. Brit. Mus., VIII, pp. 355, 417, 1870.

<Scymni, Fitzinger, Sitzungsber. K. Akad. der Wissensch. Wien, LXVII, p. 56, 1873.

<Somnioside, Jordan, Man. Vert. An. N. U. S., 5th ed., p. 15, 1888.

<Spinacida, Woodward, Cat. Fossil Fishes Brit. Mus., I, p. 30, 1889.

$=$ Dalatiide, Grll, Mem. Nat. Acad. Sci., VI, p. 129, 1892.

Subfamily SCYMNORHININAE.

<Seymnini, Bonaparte, Mem. Soc. Hist. Nat. Neuchatel, II, 1838; Nuovi Annali delle Sci. Nat., II, p. 199, 1838; IV, p. 183, 1840.

<Dalatiana, Gray, List Fish. Brit. Mus., pt. 1, p. 74, 1851.

Proc. N. M. 95-—13 


\section{$2 \mathrm{BHL}$ Biodiversity Heritage Library}

Gill, Theodore. 1896. "Notes on the nomenclature of Scymnus or Scymnorhinus, a genus of sharks." Proceedings of the United States National Museum 18, 191-193. https://doi.org/10.5479/si.00963801.18-1053.191.

View This Item Online: https://www.biodiversitylibrary.org/item/32799

DOI: https://doi.org/10.5479/si.00963801.18-1053.191

Permalink: https://www.biodiversitylibrary.org/partpdf/5699

\section{Holding Institution}

Smithsonian Libraries

\section{Sponsored by}

Smithsonian

\section{Copyright \& Reuse}

Copyright Status: NOT_IN_COPYRIGHT

This document was created from content at the Biodiversity Heritage Library, the world's largest open access digital library for biodiversity literature and archives. Visit BHL at https://www.biodiversitylibrary.org. 